\title{
Predicting Green Weight of Mesquite (Prosopis glandulosa Torr.)
}

\section{STEVEN G. WHISENANT AND DONALD F. BURZLAFF}

Highlight: Planning for commercial utilization of mesquite wood requires a procedure for estimating biomass in a given stand. A study of virgin mesquite trees at three range sites in each of seven counties of the Rolling Plains of Texas was initiated. Data revealed a highly significant linear relationship $(r=.933)$ exists between stem area at $60 \mathrm{~cm}$ above ground and the green weight of the tree. The green weight of individual trees can be predicted from a random sample of 256 trees when a prediction equation $(Y=.410 \mathrm{X})$ is used. $Y=$ green weight of the individual tree expressed in kilograms. $X=$ stem area at $a 60 \mathrm{~cm}$ height above ground level expressed as square centimeters.

Harvest of mesquite wood has been recommended in light of the potential of several commercial uses. Mesquite wood can be used as a protein source for cattle and sheep (Thayer and Young 1973; Bracher 1972). Smedley (1966) demonstrated its value as flooring material and Laundrie (1958) recommended it as a source of wood pulp. Mesquite wood has also been used to make charcoal (Durso et al. 1973) and has potential as a fuel (Wiley and Manwiller 1976) because of its high BTU content per unit of weight. These potential schemes for commercial utilization require a method of estimating yields of mesquite biomass. Not only is a yield estimate needed for commercial use but it would be of substantial value for establishing formulas for predicting spread and intensity for wildland fires (Rothermal 1972) and for studies of nutrient cycling and energy flow.

The biomass of trees has commonly been estimated by relating stem diameter to weight. Shrubs have also shown the potential for weight estimation due to the high correlation existing between stem diameters and weight of shrub parts (Brown 1976, Lyon 1970, Telfer 1969, Whitaker 1965). Brown (1976) established methods

The authors are research technician. Texas A\&M University Research and Extension Center. San Angelo 76901; former research associate. Texas Tech University, College of Agricultural Sciences and chairman, Department of Range and Wildlife Management. Texas Tech University. Lubbock 79409. This paper is presented as Texas Tech Publication No. T-9-178.

Manuscript received November 10, 1977 for estimating shrub biomass from basal diameters for 25 northern Rocky Mountain shrub species. Mesquite biomass estimation is complicated by a variable growth form which ranges from a small multiple-stemmed shrub to a large single-stemmed tree.

The objective of this study was to develop an acceptable procedure for predicting the green biomass of mesquite stands with varying productive potential found within the Rolling Plains region of Texas.

\section{Materials and Methods}

Study areas were established in Hardeman, Dickens, Knox, Fisher, Runnels, Shackelford, and Borden counties of Texas. These counties were selected because they contain a great diversity of mesquite size and growth form. Soil surveys provided by the Soil Conservation Service were the basis of site selection. Virgin stands of mesquite were used for the studies.

At each of the study areas, nine .04-ha plots were delineated and all the trees within the plots were counted, measured, and weighed. These nine plots were evenly divided among shallowland, deep upland, and bottomland sites. Measurements and weights were taken from October 1, 1975, to May 15, 1976, of 1,223 mesquite trees with a measurable stem diameter at $60 \mathrm{~cm}$. Initially, measurements were taken of height, canopy area, number of stems, stem diameter at ground level, stem diameter at $60 \mathrm{~cm}$ above ground level, and green weight of the tree. Stem diameter measurements were converted to stem area. When a tree has a multi-stemmed trunk, its stem area is an accumulation of the area of each stem. After data from the first 235 trees were analyzed, height of tree demonstrated a relatively low correlation to weight $(r=0.679)$ and was not recorded for the remainder of the study. When measurements were complete, the trees were cut as close to ground level as possible with a chain saw. The larger trees were reduced to manageable pieces for weighing. Green weights were recorded for each tree and were used in all calculations. 
Table 1. Correlation matrix of the variables.*

\begin{tabular}{lccccc}
\hline & NS & SAG & SA2 & CN & WT \\
\hline NS & 1.000 & 0.223 & 0.194 & 0.262 & 0.156 \\
SAG & & 1.000 & 0.958 & 0.859 & 0.917 \\
SA2 & & & 1.000 & 0.872 & 0.929 \\
CN & & & & 1.000 & 0.880 \\
WT & & & & & 1.000 \\
\hline
\end{tabular}

*NS = number of stems

SAG = stem area at the ground

$\mathrm{SA} 2=$ stem area at $60 \mathrm{~cm}$.

$\mathrm{CN}=$ canopy

$\mathrm{WT}=$ weight

Prediction equations, based on a linear relationship between the stem area at $60 \mathrm{~cm}$ above ground $\left(\mathrm{SA}_{2}\right)$ and green weight, were developed for each site and for the overall group of sites. Stepwise multiple regression (Dixon 1974) was used to develop a correlation matrix for the variables used in the study.

\section{Results and Discussion}

The correlation matrix (Table 1) indicates that the variables used in the study were highly interdependent. Consequently, the stepwise multiple regression analysis was abandoned in favor of a linear regression analysis between $\mathrm{SA}_{2}$ and green weight.

A significant linear relationship between stem area at $60 \mathrm{~cm}$ and green weight existed at each production site - shallowland $r=$ .892 , deep upland $r=.934$, and bottomland $r=.932$. This permitted the development of equations to predict the weight of individual trees (Table 2 ). When average weight per tree is multiplied by the number of trees per unit area for a specific site a reliable estimate of biomass is provided. Since most mesquite trees occur in stands that grow on sites of a heterogeneous nature, it is recommended that the overall formula (Table 2) be used.

Table 2. Prediction equations for estimating green biomass of mesquite trees in the Rolling Plains of Texas.

\begin{tabular}{lcccc}
\hline \hline Site & $\begin{array}{c}\text { Correlation } \\
\text { coefficient }\end{array}$ & $\begin{array}{c}\text { Prediction } \\
\text { equation }\end{array}$ & $\begin{array}{c}\text { Standard error } \\
\text { of estimate }\end{array}$ & $\begin{array}{c}\text { Mean } \\
\mathrm{kg} / \text { tree }\end{array}$ \\
\hline Shallowland & .899 & $\hat{\mathrm{Y}}=.331 \mathrm{X}$ & .1765 & 15.8 \\
Deep hardland & .934 & $\hat{\mathrm{Y}}=.403 \mathrm{X}$ & .1109 & 34.2 \\
Bottomland & .932 & $\hat{\mathrm{Y}}=.419 \mathrm{X}$ & .1061 & 57.0 \\
Ovcrall sitc data & .933 & $\hat{\mathrm{Y}}=.410 \mathrm{X}$ & .0706 & 41.0
\end{tabular}

$\overline{\mathrm{Y}} \hat{\mathrm{Y}}=$ green weight of mesquite expressed as kilograms per tree.

$\mathrm{X}=$ the stem area at $60 \mathrm{~cm}$ above the ground expressed as square centimeters.

When estimating tree weight a minimum sample of 256 trees must be measured in order to assure the precision of the precdiction (Cochran 1964). When measuring stem diameter at $60 \mathrm{~cm}$ above ground level, each mesquite must be measured unless it is less than $60 \mathrm{~cm}$ in height. Two persons can measure and record stem diameter of approximately 256 trees in 2 hours. Additional time is necessary for estimating tree density and conversion of stem diameters to area.

Determination of tree density requires the delineation of ten plots, each $1,000 \mathrm{~m}^{2}$ in area at the shallowland site and $500 \mathrm{~m}^{2}$ in area at the deep upland and bottomland sites. These plots must be randomly located within representative stands on specific sites. All trees with a height of $60 \mathrm{~cm}$ or more are counted within each plot. Number of trees per hectare is calculated from this data. Measurements of stem diameter are also made on these trees.

The density of trees, canopy area, stem area, and weight increased with the productive potential of each site (Table 3 ). The
Table 3. Average values for vegetation characteristics mesured for individual mesquite trees at various sites in the Rolling Plains of Texas.

\begin{tabular}{lccrrrr}
\hline \hline Site & Trees/ha & $\begin{array}{c}\text { Canopy } \\
\text { area } \\
\mathrm{m}^{2}\end{array}$ & $\begin{array}{c}\mathrm{SA}_{\mathrm{G}}{ }^{2} \\
\mathrm{~cm}^{2}\end{array}$ & $\begin{array}{c}\mathrm{SA}_{2}^{2} \\
\mathrm{~cm}^{2}\end{array}$ & $\begin{array}{c}\text { Green } \\
\text { weight } \\
\text { per tree } \\
\text { (kilos) }\end{array}$ & $\begin{array}{c}\text { Production } \\
\text { per hectare } \\
\text { (metric tons) }\end{array}$ \\
\hline Shallowland & 259 & 5 & 67.7 & 51.0 & 15.8 & 4.1 \\
Deep upland & 567 & 7.2 & 121.3 & 92.2 & 34.2 & 19.4 \\
Bottomland & 633 & 10.4 & 187.5 & 147.3 & 57.0 & 36.1 \\
\hline
\end{tabular}

Stem area ground level

2 Stem area at $60-\mathrm{cm}$ height

shallowland site had fewer and smaller trees than either of the other sites. This resulted in a green weight biomass of 4.1 metric tons/ha (11.8 tons/acre) of mesquite as compared to 19.4 metric tons/ha (8.6 tons/acre) for the deep upland site and 36.1 metric tons/ha (16.1 tons/acre) for the bottomlands.

The Soil Conservation Service has classified the mesquite stands of the Rolling Plains into three groups based on stand density sparse, medium, and dense. The assumption is made that this classification corresponds closely to the shallowland, deep hardland, and bottomland sites measured in this study. This makes it possible to estimate the amount of woody material available for utilization. Acreage estimates as prepared for the 1973 Brush Survey $^{1}$ indicated $1,486,630$ ha of sparse, 2,063,309 ha of medium, and 1,831,544 ha of dense mesquite in the Rolling Plains.

Based on the assumption that it would be economically unfeasible to harvest the sparse mesquite of the shallow sites (low yield. difficult terrain, it is recommended that these areas not be considered a source for commercial mesquite wood. Utilizing the yields from the plots, the data indicate that there are $40,028,194$ metric tons of mesquite from the deep hardland site and $66,118.740$ metric tons of material from the bottomland site available for commercial utilization in the Rolling Plains of Texas.

I Personal correspondence with the state range conservationist. Soil Conservation Service, U.S. Dep. Agr. Temple, Texas.

\section{Literature Cited}

Bracker, R. 1972. Cattle feed from mesquite. The Cattleman, 108 (8):43-45. Brown, J. K. 1976. Estimating shrub biomass from basal stem diameters. Canadian J. Forest Res. 6:153-158.

Cochran, W. G. 1964. Sampling Tcchniques. John Wiley and Sons, Inc. p. $71-86$.

Dixon, W. J. 1974. Biomedical Computer Programs. School of Medicine. U.C.L.A. p. 305-330.

Durso, D. F., T. J. Allen, and B. J. Ragsdale. 1973. Possibilities for commercial utilization of mesquite. Chap 3. In: Mesquite: growth and development, management, economics, control, uses. Tex. Agr. Exp. Sta. Res. Monogr. 1:20-23.

Laundrie, J. F. 1958. Pulping of mesquite, manzanita and snowbrush. Forest Products Lab, Mimeo 2138, Madison, Wisc. p. 7.

Lyon, L. J. 1970. Length - and weight - diameter relations of service berry twigs. J. Wildlife Manage. 34:456-460.

Rothermal, R. C. 1972. A mathematical model for predicting fire spread in wildlife fuels. U.S. Dep. Agr. Forest Serv. Res. Pap. Int-115.

Smedley, J. 1966. Mesquite floors for beauty and durability. Texas Forest News 45:5.

Telfer, F. S. 1969. Weight-diameter relationships for 22 woody plant species. Can. J. Bot. 47:1851-1855.

Thayer, D. W., and S. P. Young. 1973. Protein from mesquite. Noxious Brush and Weed Control Research Highlights, 1973, Texas Tech Univ.

Whittaker, R. H. 1965. Branch dimensions and estimation of branch production. Ecology, 46:365-370.

Wiley, A. T. and F. G. Manwiller. 1976. Market potential of mesquite as fuel. Forest Products J. 26(9):48-51. 